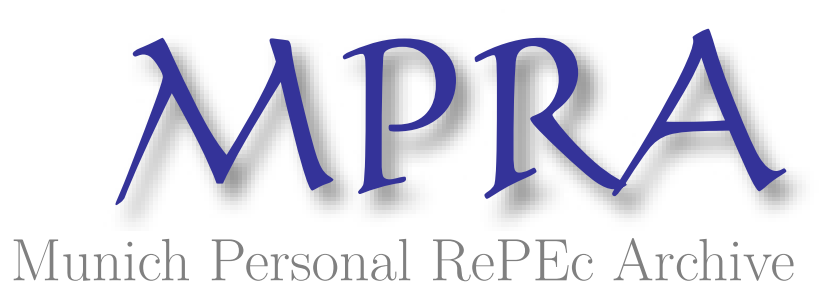

\title{
The specifics of Chinese bank regulation
}

\author{
Cousin, Violaine
}

June 2011

Online at https://mpra.ub.uni-muenchen.de/36040/

MPRA Paper No. 36040, posted 19 Jan 2012 15:06 UTC 


\title{
中监为体、西监为用 or the specifics of Chinese bank regulation
}

\section{Violaine Cousin}

\begin{abstract}
The present paper aims to propose an explanation for the rationale behind the current banking regulatory arrangement in China. A now stable and relatively healthy banking system emerged largely unscathed from the financial crisis without relying much on recognised international best practices in bank supervision. China combines a strong regulatory hand together with a capital adequacy requirements stick, without much intervention of foreign or private institutions in the larger sense of the term. After an in-depth review of the Chinese framework we recognise that it is exactly this lip service to private monitoring mechanisms on top of restrictive regulators that allows for stability and growth - at least for now. China uses Chinese supervision as the core and western regulatory instruments as useful add-ons - a manner similar to the catch phrase used over a century ago to rejuvenate China.
\end{abstract}


Barth, Levine and Caprio put their findings on best practices banking regulation in "Rethinking Bank Regulation - Till Angels Govern" and show that better banking systems are the result of private monitoring mechanisms such as international standards, transparency and disclosure, rather than strong regulators and high capital requirements. Looking at China, we do find some of these private monitoring mechanisms but we also have very much hands-on regulators and a stable banking system largely unscathed by the recent financial crisis. This paper ${ }^{1}$ aims to explain this conundrum.

First we will turn to the analysis of the current situation in China based on the framework designed by Barth, Levine and Caprio; in a second step we will then turn to the essence of Chinese-style regulation and the selective use of best practice mechanisms to finally resolve the conundrum posed above.

\section{What are best practices in bank regulation?}

In a seminal book, Barth, Caprio and Levine (2006) study what affects bank regulation and how banking regulation works. Their research on most countries show that strong regulators and capital adequacy standards "do not boost bank development, improve bank efficiency, reduce corruption in lending, or lower banking system fragility" (p. 12). They conclude that the sole working mechanism is a private monitoring ${ }^{2}$ of banks - thus supporting the case for the Basel II third pillar on information disclosure and transparency. In addition to the aforementioned two aspects, the rights of private investors and creditors also ensure strong banks.

\footnotetext{
${ }^{1}$ The present paper draws heavily on parts of "Banking in China" published at Palgrave in 2011 by the author.

${ }^{2}$ Private sector monitoring is understood there as a range of institutions in the large sense of the word, including for example international accounting standards enforced by independent auditors, international rating agencies, foreign (thereby external to the state) shareholders or accession to the FATF to fight money-laundering. Any type of international standards reflecting best practice is a tool of private sector monitoring. In China, it is not possible to consider industry associations, legislature or payment system institutions as independent from the state. They do not constitute private monitoring mechanisms.
} 


\section{Table 1 Summary of banking regulation indicators for China according to Barth, Caprio \& Levine}

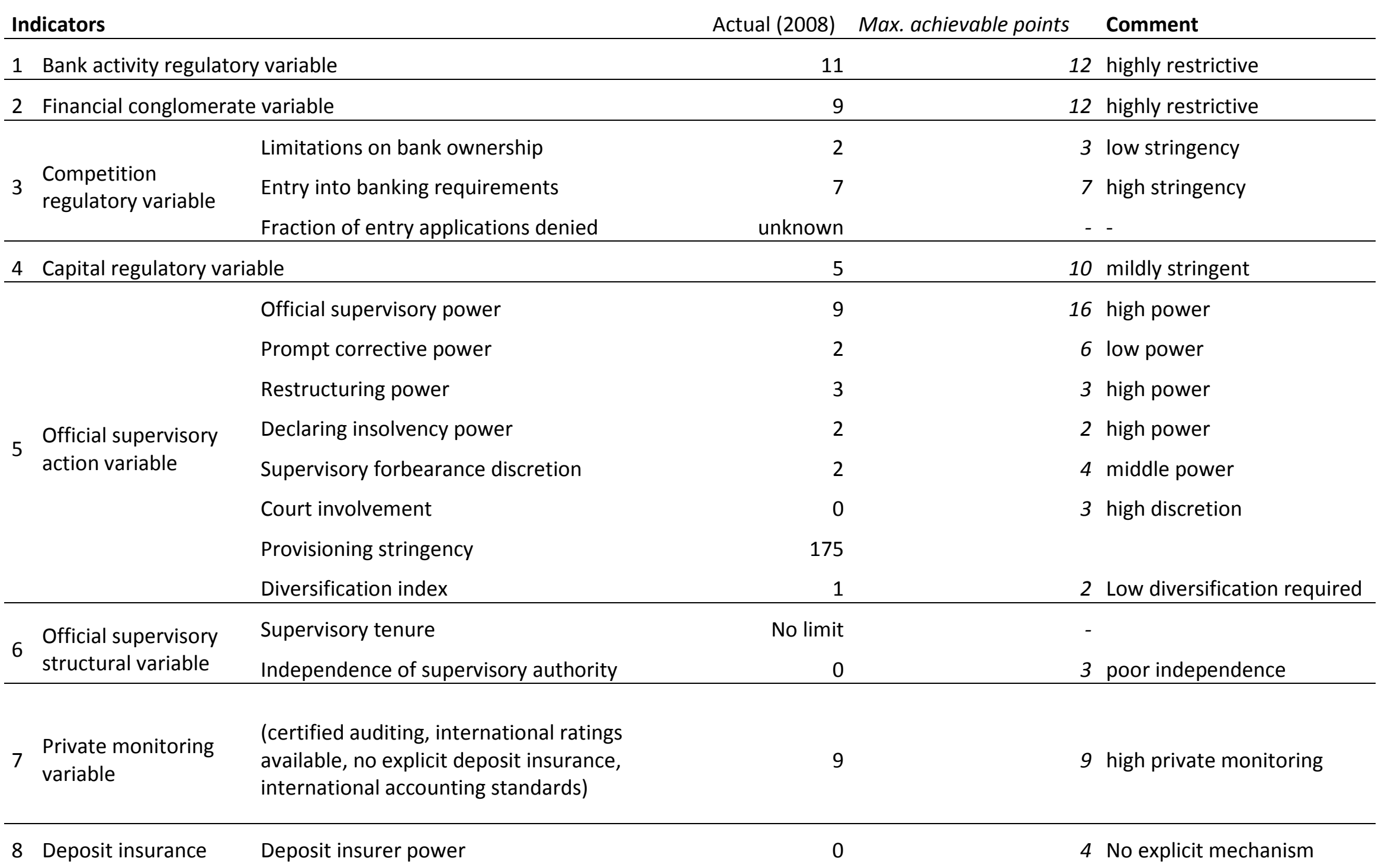




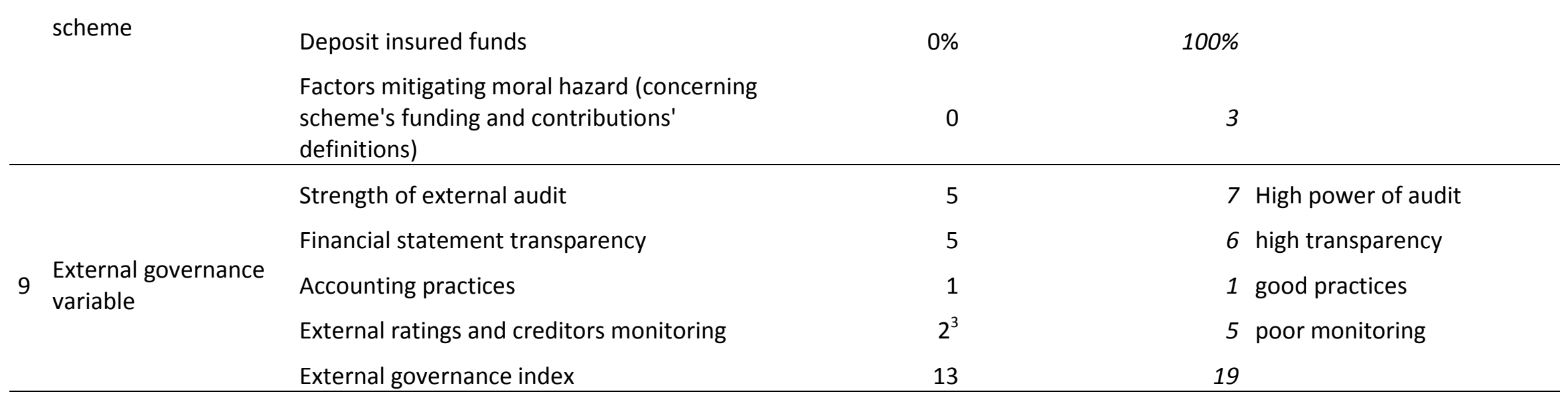

Source: author's own research, framework based on Barth, Caprio and Levine (2006).

\footnotetext{
${ }^{3}$ On this, China scores less because subordinated debt is only to a limited extent allowed to be included in capital calculations - since mid-2009 even less so because cross-holdings between national banks are not recognized anymore.
} 
From table 1, it is clear that regulators in China retain a restrictive stance over the banking sector and that they are powerful. Their handling of licences for new institutions, new branches and new lines of business is highly restrictive and works on a case by case basis. For foreign institutions, acquisitions and capital participation in Chinese entities are limited to $20 \%$ control. Supervisory action is fully controlled by the China Banking Regulatory Commission (CBRC). If not, it is done so by the central bank (People's Bank of China, PBOC). Involvement of the judicial or legislative powers is highly unlikely or even impossible. Meanwhile, regulators lack independence from the state apparatus and there is no explicit deposit insurance mechanism as mentioned above (thus the values of the indicators in the above table might give a misleading impression because it does not account for an implicit yet credible mechanism).

The most interesting factors here are the private monitoring variable and the external governance variable. The first describes whether certified auditing is required, whether the largest ten banks are rated nationally and internationally, and which accounting standards are in use. The second indicator relates to the quality of external auditing, the transparency of financial information as well as accounting practices and use of credit ratings. While both cover similar issues, it is striking how external governance and private monitoring score - bearing in mind such a pervasive state ${ }^{4}$. The strength of both at the same time appears a contradiction to the findings of "Till Angels Govern".

Meanwhile, Chinese banks appear going from strength to strength - beating the world's largest banks in terms of valuation, standing and performance. While their asset base has grown, they have managed to shed non-performing loans. Cleaning the books was accompanied by leaner internal structures and more modern risk management techniques as well as benevolent strategic minority foreign shareholders. The country's largest banks can now show on average return on equity that tops $15 \%$ and return on assets around $1 \%$. Their capital adequacy of around $11 \%$ is the envy of most of their Western counterparts. What's more, they seem to have withered the financial crisis almost unscathed ${ }^{5}$.

Thus when applying the model designed by Barth et al., one rapidly must acknowledge that even though regulators are strong and the Chinese banking sector shows strengths, private monitoring mechanisms show a mixed picture - at times powerful, at times poor. The discussion that follows will attempt to explain this - in apparent contradiction to Barth et al's findings.

The reform movement of 1898 in China rallied a number of scholars around the catch phrase of 中学 为体、西学为用 [zhongxue wei ti, xixue wei yong] ("Chinese learning should remain the essence, but Western learning be used for practical development", in short tiyong ${ }^{6}$ ). It came to symbolise one of the answers to the challenges posed by the entry of foreign powers in the late 19th century. The formula proposes to use Chinese teachings as the basis to resolve issues China faced but at the same time to use western technology and science to strengthen the country.

The present paper proposes to rewrite the tiyong-formula as 中监为体、西监为用 [zhongjian wei ti, xijian wei yong] (Chinese style [banking] supervision should remain the essence, but Western style [banking] supervision be used for practical development) to fit closer Chinese regulatory reality. This

\footnotetext{
${ }^{4}$ In the present paper, the author uses "state" as a collection of central and local authorities, encompassing all levels of administration and all kinds of ministries and agencies of the state (and therefore of the Communist Party). The terms "local authorities" and "local governments" are used interchangeably and this encompasses authorities in the townships, provinces, municipalities - in fact the antithesis to the central authority or central government.

${ }^{5}$ Although loan quality should be taken with a pinch of salt, since it normally takes two to three years to see any tangible result on quality. For an updated review of the banks' performances, the reader might wish to consult either "Banking in China" by Violaine Cousin or the yearly published China Hand - Finance chapter at the EIU.

${ }^{6}$ See Spence, J. D., 1990, p. 225.
} 
new tiyong-formula embodies the fact that - as argued here - Chinese banking regulators use their own specific approach to supervision to which they add up a number of western oriented features (deemed best practices). Consequently the regulators have a very flexible and unique way of understanding and implementing supervision. This flexibility allows regulators to respond to changes in the environment and the industry over which they preside. The emphasis is on Chinese structures while selected Western ones serve a very practical and well defined purpose.

\section{Zhongjian wei ti - the essence of Chinese bank regulation}

What is the essence of Chinese bank regulation? If one word would suffice as answer, it would be the state. Nonetheless it is still necessary to describe the Chinese supervisory framework in more details to underline how pervasive the state is in China and in Chinese banks.

\section{The state is the regulatory authority}

The banking sector is mainly under the supervision of the People's Bank of China (PBOC) and the China Banking Regulatory Commission (CBRC).

The People's Bank of China (PBOC) served its first 30 years as a conduit for short-term working capital loans to state-owned enterprises to fulfil the annually set credit quota. Its focus on central banking functions is the result of progressive reforms in the last 20 years. Since the establishment of a specialised regulator for banks, PBOC does not interfere in the daily supervision of financial institutions. However it often discusses general issues, such as the strategic direction of reforms and their goals, and retains the role of lender of last resort. Because it has the responsibility for the stability of the financial system, it also needs to evaluate the riskiness of the financial system to prevent and solve financial crises (Xiao Z., 2005 and PBOC, 2005).

To increase the independence of the central bank and the efficiency of the regulatory function, the central government established in March 2003 the China Banking Regulatory Commission (CBRC). The CBRC is the supervisor of financial institutions under the leadership of the State Council ${ }^{7}$.

Its goals and responsibilities are stated in the Law on Banking Supervision and Administration and these include: defining of relevant rules and regulations for supervising financial institutions in China, licensing financial institutions, conducting off-site and on-site supervision of all financial institutions, approving the adequacy and qualifications of senior management in these institutions, and making proposals for resolving banking crises or high risk situations in the banking system. The CBRC can fire top senior managers and issue fines when an institution or an individual violates rules. In their daily work PBOC and CBRC issue administrative rules that should help implement and regulate the laws issued at a higher level. These rules define the business scope of financial institutions and the permissible activities as well as basic licensing requirements ${ }^{8}$.

\footnotetext{
${ }^{7}$ The State Council is the highest executive organ in the state administration. Under the State Council are ministries, commissions and bureaus. It is further represented through government authorities at provincial and local level. The National People's Congress (NPC) represents the legislative. It is represented at national, regional and local levels. Current affairs are dealt with by their respective standing committees. The judicial power is represented by People's Courts. Preliminary administrative rules may be issued by the State Council, but the NPC must enact a proper law after a time (Wei W., 2005). Running in parallel is the party hierarchy: above all sits the Politburo standing committee with nine members. Below that is the Politburo itself with the Central Discipline Inspection Commission (CDIC) and the Central Military Commission. The third level is made up of the Central Committee of the Communist Party of China (CPC). To this a number of leading groups (economics, finance, agriculture, and so on) and of departments (Organisation Department (OD), propaganda and so on) as well as local committees (provincial, city, county and so on) report to it (McGregor, 2010).

${ }^{8}$ Apart from being under the regulatory authority of the PBOC and the CBRC, banks also fall under the China Securities Regulatory Commission (CSRC), which is in charge of regulating the securities markets. Furthermore, they also have to follow the regulations of the State Administration of Foreign Exchange (SAFE) which manages currency reserves and the exchange rate (under the PBOC umbrella). Other departments or ministries also influence the banks' operating environments: the Ministry of Finance is responsible, among others, for
} 
The multiplicity of regulatory bodies is one source of additional costs and risks to the banking system. Another one is the competition between regulators, exemplified over the issue of macro-prudential regulation, . The PBOC still views itself as the guardian of financial stability in China, and the CBRC considers that its counter-cyclical policies (such as higher capital buffers and provisioning) will be sufficient to avert any crisis in future.

The regulators have in their hands a number of instruments to ensure that their own goals are met. Although China is progressively moving away from decree-based towards rules-based regulation, the degree to which administrative steering is preferred over interest rates and other objective instruments depends on the environment.

$\mathrm{CBRC}$ and $\mathrm{PBOC}$ both still use quotas or injunctions to banks to ensure enforcement, to support the state sector in general or to direct funds to specific economic sectors or regions. During 2008-09, the PBOC used its injunctions to first induce the banks into lending more to support the fiscal stimulus and then to calm the loan growth that appeared too strong and could potentially carry large risks. Higher deposit requirements were used only at the end of that period. Further administrative controls were introduced as well to reduce lending in overheated sectors such as real estate and construction. Finally the impact of market instruments is reduced by the fact that the Chinese economy still depends to a large extent upon administrative steering.

Additionally the banks define their own lending limits or quotas and these are discussed and possibly adjusted with the regulator (Wall Street Journal, 2010a). 'Window guidance' meetings take place both ways: to increase or to curb loans at large commercial banks in order to either support growth or to keep credit risk in check (Li T. and Wen X., 2009). For larger loans, the system works the other way round: banks become simple utilities at the hand of the authorities (such as ministries overseeing a whole industry) (The Economist, 2010a).

Another instrument was used to curb lending, a hybrid between market and administrative measures: forced sales of PBOC bills to large lenders (Zhang M., 2009 and Huo, K., Wang J., Yu H. and Wang L., 2009). All these administrative measures - while being legacies of a socialist economy - also have advantages: they still can be useful when authorities do not wish to raise interest rates which would hurt certain economic entities with higher interest costs.

A final concern to Western scholars is the independence of regulators. The de iure independence which is written down in the relevant regulations and laws does not guarantee a de facto independence. While the promulgation of the Law of the People's Bank of China and the Law on Banking Supervision and Administration has enhanced the regulators' scope for action, both remain under the pervasive influence of the State Council. For some important decisions, regulators are required to get the approval of the State Council first.

All regulators, among which are $\mathrm{PBOC}$ and $\mathrm{CBRC}$, are established under the State Council and are subordinated to it. Committees in both PBOC and CBRC are mostly staffed with personnel from the Communist Party chosen by the State Council. Furthermore, the capital of the PBOC is fully in the hands of the state, under the State Council. The regulations do not give any details of the duration of a chairman's or governor's term; the person can be removed or transferred whenever deemed necessary - the same is true for CBRC. Through the committee for monetary issues, the National People's Congress also gets an opportunity to oversee the work of the PBOC (Wei W., 2005) - but cannot control the issues it deals with nor ask for investigations over its role. The same holds for CBRC.

Political influence is also eased by the fact that the organisational structure of the PBOC runs almost in parallel with that of other administrations (although now regional offices do not report to provincial governments any more). Theoretically any type of political influence at local level is

promulgating accounting and tax rules and the NDRC (National Development and Reform Commission) is responsible for enterprises finance issues and industry policies. These two institutions are very powerful and have an overarching role in defining future policies. 
forbidden (for example amended law for CBRC, Art. 5). However local authorities' cooperation is required in resolving and investigating problem institutions.

The independence is further dented by the lack of independent financial resources, even though CBRC collects supervisory fees. The fees are actually forwarded as part of the central budget and the Ministry of Finance then allocates the annual budget required by the CBRC in return. At least, professionalism has certainly increased and regulations have provided more power.

As a result from the strong influence exerted by the State Council, PBOC and CBRC cannot be made fully accountable for their policies and actions - although their staffs face fines and penalties for misconduct. Their subordination to the State Council reduces the degree of achievable functional, institutional, personal and financial independence.

A final comment is necessary on the role of the Communist Party in the banking sector, which is right behind all state organs and regulators or financial institutions and their borrowers. All important and strategic decisions affecting the finance sector are ultimately reviewed and taken by the Leading Group for Finance and Economics ${ }^{9}$ - a group under the guidance of the party and staffed by high level government bureaucrats. The Financial Work Conference which meets every four years to decide upon the reforms of the financial system is run under its aegis.

\section{The state is the banking safety net}

With the banking institutions playing a central role in the financial system in China, a safety net is crucial to ensure prompt resolution of any crisis touching the central nerve of the economy. The PBOC acts, as described above, as a lender of last resort and the CBRC has the power to take over failed institutions. So exit mechanisms for banks are part of the legal infrastructure and come mainly in two forms: through deposit insurance and through bankruptcy proceedings.

As a second line of defence behind the lender of last resort - but before a government bailout, deposit insurance could have a role to play - however, in China it is still not a reality. While the financial crisis has highlighted the need to have a functioning deposit insurance mechanism and not to dismantle completely a financial safety net (that is to leave the oversight to depositors), disagreements over the mechanism's structure in China have kept any compromise from becoming reality.

The current implicit arrangement is that banks are rescued by the state - either through forced mergers, outright closures, restructurings, name changes or re-lending facilities. It has already showed its willingness and capacity to do so in various cases with urban and rural credit cooperatives, with large and smaller commercial banks. The financial crisis in 2007-09 has confirmed their expectation even further.

So one might rightly ask what would be the difference between being taken over by the state or by a deposit insurance institution right below the state. Bank managers would be relieved of their responsibilities in any case. Under both implicit and explicit arrangements, Chinese depositors do not need to be vigilant of reckless risk-taking in banks - safety is given at all times. Although a deposit insurance institution would add a pair of eyes in supervision to increase systemic stability but watchful eyes might become costly beyond what is necessary. Speed of resolution could possibly be hampered if three instead of two regulatory agencies compete for taking over the failed bank.

It is always the state that bails the banks or the system out. The state takes either the form of a lender of last resort (PBOC) or of the main or sole shareholder (through Central Huijin Investment $\mathrm{Co}$, (Huijin) or the Ministry of Finance (MOF)). If bad loans are such that recapitalisation is required, then the shareholder aka the state steps in with fresh capital (that is, a government bailout is also a

\footnotetext{
${ }^{9}$ According to Miller (2008), the Leading Group for Finance and Economy (中共中央经济小组) is one of the most important decision groups within the state apparatus. It was reinstated in March 1980 and was chaired then by Zhao Ziyang. Currently Wen Jiabao is the chairman. It is staffed with high level chairmen of the relevant ministries and regulatory bodies.
} 
bailout by shareholders). If banks experience a run, the state implicitly guarantees the repayment of almost all deposits (any bank would count as "too big to fail") - so that the risk of a social crisis is eliminated (as long as the state has the resources to fulfil its promises).

With such credible and tested implicit deposit insurance, there is no need to establish an explicit mechanism. Banks would forego earnings when paying for the deposit insurance scheme which they now distribute to their shareholders among which are individual investors (but to a greater extent to the state as shareholder). As a majority shareholder the state can set the level of required dividends and taxes the banks should pay - funds that can be used by the same state when in the role of a saviour.

The bankruptcy of banks mechanism does little to improve such situation. The new Bankruptcy Law was promulgated in 2006 but deals only succinctly with banks. Only their supervisor is allowed to apply for bankruptcy for them - once PBOC has approved of the proceedings (Commercial Banking Law). Further details are to be worked out by the supervisors themselves or can be gleaned from the Rules on dissolution of banks. Dissolution can be ordered for a number of reasons including unlawful activities, mismanagement, and not only inability to repay debts. The rules describe the process of dissolution and management of the dissolved entity, but do not actually regulate debt issues.

However, these regulations are not frequently used for banks. More often the authorities use an administrative decree rather than legal means to resolve problems faced by individual banks. The reason for preferring such methods is the stated goal of social stability.

In China, as in many other emerging or developing countries, adherence to such arrangements however creates moral hazard problems and reduces incentives for introducing best practices in banking. Thus recently, Chinese regulators have made calls for increasing market discipline and reducing the likelihood of administrative state bailouts.

\section{The state is the financier}

In each of the state-owned commercial banks (SOCBs) the state holds directly over two thirds of their capital (either through Central Huiin or through the Ministry of Finance). Their listings did not fundamentally alter the majority holdings - and did only clarify the holding entity. In all other banks, the state also holds banking assets indirectly through local governments and state-owned enterprises. While measuring the actual holdings of local state-owned enterprises in each bank's capital is near impossible now, researchers assumed in 2004 that the Chinese state held between 95-99\% of all banking assets (Bekier, Huang and Wilson, 2005). Even though listings have increased the number of shares held privately and state shares reform has also transformed the listed shares into liquid ones, the total percentage might have dropped by a few percentage points only. Furthermore the state shares are not likely to be sold in any case as it is the state's goal to keep them under its control. The only bank whose capital is in majority privately held is China Minsheng Bank.

Through controlling equity stakes, central and local authorities exercise a so-called lishu (隶属) relationship: the entity's owner is entitled to direct control over that entity. Such relationship is not based solely on ownership rights. Control can be exercised administratively where necessary (Tan et al., 2007). Depending on such relationship, environments might be more lenient or more supportive of a firm's development - depending on the local government exercising the power (incentives can take the form of tax holidays, subsidies, loan applications, licences and so on to facilitate transactions). Closeness to varying levels of government enhances performance and the firm's prospects (this is especially true at township level or below, and at central level).

Apart from having a controlling equity stake in the banking sector, the Chinese state has also provided generous financial support to financial institutions. Overall, up to 2006, the state has spent around CNY2.3trn to support the main commercial banks - through fresh capital injections in 1998 and in mid-2000s, transfers of NPLs to the four asset management companies (AMCs). The SOCBs were certainly not the only ones supported. PBOC issued special bank bills in June 2008 amounting up to CNY165.6bln in exchange for NPLs totalling CNY135.3bln to help rural credit cooperatives 
restructuring. Between 2005 and 2008, Central Huijin injected fresh capital to replenish the four SOCBs.

Local governments have also had to rescue their local financial institutions as they were required to do so by the central authorities and as they held most of the capital in these institutions. No data is available on the total amount of financial support provided, but experience has showed that the local authorities could not avoid rescue operations with restructuring efforts and to address NPL problems.

\section{The state is the businessman}

Before the start of the reforms in 1978, the banking system was just one of many parts of a huge state administration. Financial flows were organised around the planning exercises for the whole economy and flows were directed to specific industries and regions based on political decisions. Since then, the authorities have remained influential in the decision making process of banks, especially larger ones. While credit quotas have been removed, practices remain, especially for large government projects and SOEs (in disregard of creditworthiness and repayment ability and willingness). This is not only the case with central authorities, but also with local ones.

The Chinese state has business interests. As illustrated by Shih (2004), the Chinese authorities can obtain private gains and advancement through bank loans. He showed that more loans were likely to flow to a specific province when that province was headed by a party official with ties to the central leadership. Another way of increasing the flow of loans is to generate more revenues for the central government (Shih, 2004). For many local governments a tight grip on bank lending decisions can help develop the local economy by securing financing for infrastructure projects and real estate development (local governments have a monopoly on land, and thus on land prices and land transfers; The Economist, 2006).

Additionally, the reforms of the state banking sectors are a mean to realise the state's assets rather than a true privatisation. The restructurings never changed the balance of power at the banks but rather enabled the Party to strengthen its leadership and to broaden its power based on written rules (corporate governance rules and laws for example).

In order to achieve the highest gains on its assets, the Party has required bank executives to run the companies and banks it ultimately owns in a commercial and market-oriented way. The structures ensure in the end that the revenues thereby generated flow to the Party itself. It is therefore unlikely to relinquish any of its current powers, rather the Party uses foreign ways and ideas to sustain its own future.

In some cases, the state appears to use bank lending to compensate for lower levels of government spending and government financed projects. Thus local authorities needed to take more influence on the lending decisions and processes, to politicise lending. At the same time this weakens the power and pressure that regulators can put on local financial institutions. While corporate governance mechanisms have limited the influence channels of party and local governments, these have not been removed completely (Heilmann, 2005a).

\section{The state is the employer}

The above-mentioned Leading Group for Finance and Economics is also working together with the Communist Party's Organisation Department ${ }^{10}$ to oversee senior appointments at both authorities

\footnotetext{
${ }^{10}$ The Organisation Department is a highly secretive and massive organisation which is in charge of human resources on behalf of the Communist Party. It penetrates every state entity within the country - regardless of it being private or not. It acts behind closed doors: it conducts candidates' interviews and investigations, removes and changes positions of senior managers and bureaucrats. As a result is it also the place of strong political battles so far that posts can be bought and sold. Appointments depend on experience, education, and so on. Indicators inform about the executive's performance. Its professional head-hunter practices work up to a certain official rank only however. Promising officials are rotated between enterprises, industries, departments and regions (McGregor, 2010).
} 
and financial institutions (lower level managers are proposed by the firm's party committees and vetted by (BRC). The blurred dividing line between Party and state leads to yearly rounds of "musical chairs" where senior managers rotate from one financial institution to another ${ }^{11}$. "[...] the most significant feature of the Chinese banking system was the pervasive influence of the Chinese communist party, which induced a high sensitivity among bankers to political signals from the top." (Shih, 2009: 31) Party members answer to the Party first. For state-owned banks, as the majority or sole shareholder, the authorities have the right to choose senior managers. The Party permeates every level of the state - but it remains on the sidelines - without being a simple watcher: it has the strings in its hands.

Foreign observers should not be misled by the fact that personnel changes are announced by relevant ministries or regulators or by the fact that no official and publicly available bank documents mention the Party. Banks are instruments of national economic policy and will have to act along the Party lines where necessary (the rules and regulations are nonetheless issued by the relevant ministries and departments). The same applies to senior appointments. To ensure social stability and successful macroeconomic policies, the Party - through the bank's individual Party Committees - is in charge of personnel and strategic issues.

This is in line with the government's policy of choosing senior managers and board members reflecting political credentials rather than business acumen ${ }^{12}$. This activity is euphemistically called "leadership" rather than "interference" (McGregor, 2010: 23). The authorities also have the power to remove or transfer the managers as it sees fit, in all banks in China: some $80 \%$ of CEOs and $56 \%$ of senior executives in SOEs are appointed by the party (Pei M., 2006).

Table 2 Chairmen's and presidents' previous positions (selection)

\begin{tabular}{|c|c|c|}
\hline Bank name & $\begin{array}{l}\text { Chairman name and other } \\
\text { previous positions }\end{array}$ & $\begin{array}{l}\text { President name and other previous } \\
\text { positions }\end{array}$ \\
\hline \multirow[t]{2}{*}{ ICBC } & Jiang Jianqing* & Yang Kaisheng \\
\hline & $\begin{array}{l}\text { Member of Central } \\
\text { Committee of CPC, PBOC }\end{array}$ & Huarong AMC \\
\hline \multirow[t]{2}{*}{$\mathrm{BOC}$} & Xiao Gang & Li Lihui \\
\hline & $\begin{array}{l}\text { Member of Central } \\
\text { Committee of CPC, Orient } \\
\text { AMC, PBOC }\end{array}$ & Vice Governor Hainan, ICBC \\
\hline \multirow[t]{2}{*}{ CCB } & Guo Shuqing* & Zhang Jianguo \\
\hline & $\begin{array}{l}\text { Member of Central } \\
\text { Committee of CPC, SAFE, } \\
\text { PBOC, NDRC }\end{array}$ & ICBC \\
\hline \multirow[t]{2}{*}{$A B C$} & Xiang Junbo* & Zhang Yun \\
\hline & $\begin{array}{l}\text { Member of Central } \\
\text { Committee of CPC, PBOC }\end{array}$ & - \\
\hline \multirow[t]{2}{*}{ Industrial } & Gao Jianping* & Li Renxing \\
\hline & - & PBOC \\
\hline
\end{tabular}

\footnotetext{
${ }^{11}$ For example in June 2007, Tang Shuangning, previously vice-chairman of the CBRC, was appointed chairman of the board of China Everbright Bank. Similarly, Xu Feng, former director of CBRC became president of the Shanghai Pudong Development Bank and Xiang Junbo, a deputy director at PBOC was named president of the Agricultural Bank of China (Anderlini, 2007).

${ }^{12}$ In November 2004, the previously required party membership for middle management has been removed at Bank of China and China Construction Bank (Zhang X., 2004b).
} 


\begin{tabular}{lll} 
Huaxia & Wu Jian* & Fan Dazhi \\
\multirow{3}{*}{ Minsheng } & ICBC, BoComm & Smaller NBFIs \\
& Dong Wenbiao & Hong Qi \\
SPDB & PBOC & BoComm \\
& Ji Xiaohui* & Fu Jianhua \\
& ICBC, Shanghai municipal & CCB \\
& government & \\
BoComm & Hu Huaibang & Niu Ximing \\
& CBRC, PBOC & ICBC \\
Merchants & Qin Xiao & Ma Weihua \\
& CITIC & - \\
Everbright & Tang Shuangning* & Guo You \\
& CBRC, PBOC, CCB & SAFE, PBOC \\
\hline
\end{tabular}

Note: the selection should not suggest that all other banks' senior managers have similar career paths. The positions show only the name of the institution - other than their current institution, the positions held might have been numerous and at different levels of hierarchy. The list entails only presidents and chairmen of the boards as of end-2009. The information does not include other positions held in universities and other nonbank or non-government institutions. * Those with an asterisk are also mentioned as Party Committee secretaries in the annual reports. This
information is given in a few annual reports only.

- Means that the person did not held any positions in other banks or authorities.

Sources: http://www.chinavitae.com/index.php and banks' annual reports.

Such policies are now centralised at highest level which reduced the influence of local and regional offices and authorities (Heilmann, 2005a). This enabled the management of the banks with higher efficiency and more consistency (through higher party discipline, less loopholes allowing rent-seeking, and so on). But the high level of decentralised management in Chinese banks still allows local authorities to intervene at branch level - through "financial services offices" which are set up to provide administrative services to financial institutions (such as encouraging their establishment in certain geographic areas). Now they intervene less in appointments and rather in rules enforcement.

Under such conditions, managers are given the incentive to reach a higher position in their (political) career rather than profit maximisation (Goodhart and Zeng, 2005). In his interviews, Victor Shih found that "the single clearest message that emerges [...] is that, above all else, Chinese leaders care about political survival and actively formulate strategies to expand or maintain power" (Shih, 2009: 16). Excessive risk taking is not incentivised because managers of banks are being rotated from one position to another. They risk their own career rather than their bank's financial standing ${ }^{13}$. Such risk aversion does not preclude some lobbying however. Where rules appear too strict, banks do not refrain from lobbying in order to achieve more lenient regulations (as for example for the recognition of cross-holdings of subordinated debts into the capital adequacy calculation; Fang H., 2009).

The supervision of the bank managers after their appointment is twofold: political acumen or party discipline is the responsibility of the Central Discipline Inspection Commission (CDIC) which encompasses corruption, compliance with party policies, and so on. The second one is based on

\footnotetext{
${ }^{13}$ “Even highly insulated bureaucrats in a professional bureaucracy have an interest in getting promoted, and financial resources constitute a powerful policy tool that can quickly bolster one's administrative accomplishments and thus speed up promotion." (Shih, 2009: 8)
} 
professional standards encompassing compliance with lending ratios and quotas as well as quality indicators (McGregor, 2009). Bank performance is linked to compliance with regulatory prudential ratios and market shares (Wen X., Zhang M. and Fang H., 2009). These are only tested by PBOC and/ or CBRC (Shih, 2009).

\section{Pervasiveness of the state}

As shown above, the state permeates every area of the financial system: as the regulator, as the provider of emergency funds, as the provider of indirect and implicit guarantees to all commercial banks, as the dominant shareholder in banks, and as an employer.

All above roles are not independent from one another; they are all part of the same entity: the partycum-state. The interference of the state or the party is pervasive and permeates all decision areas, all economic sectors and all institutional levels. At least the state lends to these institutions its good international credit ratings. It also ensures support to an investment-led GDP growth.

Unfortunately, the state or even the party is not one but many: the state includes the central government, a wide range of local governments, regulatory agencies, ministries and other administrative units. These often have conflicting and contradictory views, and compete for power and prestige.

All entities fear a loss of power and control over the activities in the financial industry, over the allocation of funds and resources, over decisions and over ownership. This high number of actors in the financial industry can have a strong influence on decisions and on compromising arrangements, but also points to a strong potential for conflicts.

Victor Shih has found a powerful explanation behind the seemingly shifts of power between the many entities within the state (Shih, 2009). He finds that power changes hands between two types of factions: the generalist faction running vertically from central to local governments and the technocratic faction which runs horizontally at central leve ${ }^{14}$. The first sort of faction is mostly interested in the unhindered flow of financial resources to their own projects - mostly in their provinces. The second faction type is focused, on the contrary, on financial centralisation because their ability to solve financial challenges is the basis for promotion. The two types of factions succeed to one another around an equilibrium state that ensures that lending and inflation are sufficient without being too high to ensure the creation of financial resources of the state. ${ }^{15}$

\footnotetext{
${ }^{14}$ A faction is a "personal network of reciprocity that seeks to preserve and expand the power of the patron", which is formed based "on personal relationships between the patron and its clients" and which "exists as a channel to exchange goods and influence". Generalist factions have the highest power, while the technocratic factions arrange themselves around specialised mandates such as in the financial sector (Shih, 2009). A member of a faction gets promoted either because he/she brought additional investments and resources to his/her home province (mainly through loan allocation because they can form the largest fund volumes) if he/she is part of a generalist faction, or because he/she shows sufficient authority to have the resources to be spent in case of need or financial problems if he/she is part of a technocratic faction. All are rent-seekers nonetheless.

${ }^{15}$ Alternative views to explain the country's reform path also include one which puts modernist and conservative faction vis-à-vis and other one which puts centralisation vs. decentralisation efforts at the centre of the explanations. The former explanation fully fails to recognise the fact that loyalty is to the Party and/or to a person (or a faction) and not to an idea and that the centre-periphery relationship is of paramount importance in Chinese governance: "the dominance of the centre is the precondition to guarantee the unity of the state" (Weigelin-Schwriedzik, 2004). At the same time the periphery - through local authorities - ensures the enforcement and implementation of decisions of the central authorities which also devolve a number of other duties and responsibilities to the peripheries. The relative independence of local authorities or the periphery allows for a larger unified state while spending fewer efforts in controlling it. The means to ensure that the relationship remains stable (apart from guaranteeing unity) include control over human resources and the bureaucracy, the armed forces and the propaganda (McGregor 2010). These three pillars ensure that all are loyal to the Party and speak in one voice. The bureaucracy embodies the complementary link between centre and periphery. This arrangement has endured over the long Chinese history. A failure to balance out power and
} 
Not only does such model explain recurrent episodes of low and high inflation as well as economic growth but it also supports the idea that the banking reform agenda is fully in the hands of the political elite. The seemingly pro-market reforms introduced in China in the last ten to fifteen years are the result of the technocratic faction being successful at erecting mechanisms to mitigate the effects of the expansionary and decentralising stance of the generalist faction (for example through risk management ratios ${ }^{16}$ (capital, lending, asset quality limits), through the centralisation of senior bank appointments, the timid introduction of private monitoring mechanisms). The mitigating mechanisms are not a kow-tow to private markets and players or reflections of an intrinsic interest in pro-market reforms: they are much more instruments of power to stabilise around the equilibrium state (between the two factions) and avoid too large deviations which would be costly to the state.

Recent success with large-scale IPOs have allowed the state to collect the fruits, that is, capital which does not need to be repaid together with dividends. Partial listings are the rage - just as jointventures were the answer to the early years of reform and opening policy - because on one side they provide much needed technical knowledge and capital (and additional layers of independent oversight) without using state resources (even creating additional revenues from investments) and on the other side few strings are attached and neither power nor influence are relinquished.

To ensure keeping the status quo, reforms need to focus on truly reliable control mechanisms and structures - private ownership and market forces would unfortunately mean a loss of power for the ruling elites. Thus, Zhou Xiaochuan argued in an article in the People's Daily in 2000 that "to preserve sufficient state control and defence capacity against external shocks during a period of economic system transformation and of further opening to the outside world, the state can preserve an absolute right of control over some large commercial banks, for example 75\%." (republished in Zhou, 2005).

\section{Rationale for state interference}

Chinese regulators follow a very hands-on approach to regulation as they represent extensions of the state. Their role is to ensure that fruits of the banking system do indeed flow to the state itself (being in the form of state-owned enterprises with lower costs of funding or state coffers refilled with dividends and taxes paid by the financial institutions).

Nevertheless, the basis for regulatory intervention follows the same pattern as Mandanis, Schooner and Taylor (2009) assert: intervention is the result of three market failures namely existence of monopoly power (banks as a group form a strong monopoly in finance intermediation with enterprises and individuals), the existence of negative externalities (failure is then fully covered by the state) and to reduce information asymmetries (regulators concentrate a high level of information and of data from banks, either reported or inspected - the regulators play that role for the state).

The regulators interact between state and banks and not as usually between bank customers and banks themselves. The objectives of financial supervision are still to promote systemic stability, efficiency and competition, to ensure market confidence and protect depositors. These goals are points on the overarching goal of keeping the political elite in power - by allowing it to reign in a stable and predictable environment and by providing it the necessary financial resources for further development.

control between centre and periphery may lead to a change of regime. The latter explanation concentrates on the fact that political and fiscal decentralisation allowed local authorities to use resources as they pleased and to test different policies locally to innovate. Authors however found that this did not explain China's economic miracle (Cai, Treisman, 2006).

${ }^{16}$ As noted by Shih (2009), the first introduction of such limits and ratios came only after the Asian Financial Crisis which provided the technocratic faction with a powerful rationale and narrative to restrict the power of the generalist faction. 


\section{Xijian wei ti - the practicality of private monitoring mechanisms}

To illustrate how private mechanisms are used in the Chinese regulatory framework, we will analyse the entry of foreign investors into China, as an example. Other mechanisms among which are the enforcement of prudential ratios for liquidity and capital adequacy for example, accounting standards which in China now in most aspects reflect international ones, the limited entry of international rating agencies which actively and for the last decades have rated most large Chinese banks, or since 2007 the new internationally wetted anti money laundering rules, all have been selected to serve one single purpose.

Since 1991, when the Asian Development Bank acquired a stake in Xiamen International Bank, foreign banks have started buying stakes in the capital of Chinese banks. Most of the deals have taken place between 2004 and 2006, after CBRC raised the ceiling on individual stakes to $20 \%$ and overall on foreign stakes to $25 \%$ in the capital of any type of Chinese bank (including RCCs) in December 2003. Further to this, in January 2006, CBRC announced that foreign investors can invest in "up-to-now off-limits" A-shares. Overall, individual foreign institutions' stakes range between 2 and $20 \%$. As of end 2008, foreign investors had taken equity stakes in 31 Chinese banks (approved) and their equity participations amounted to some USD 32.7 bln (a further USD 45.5 bln were raised through market listings, CBRC, 2010).

Getting a share of the growing Chinese market is further limited by principles laid down by $\mathrm{CBRC}^{17}$ : no controlling stakes in large banks, foreign investors should bring in strong management experience and technical skills, the investing institution should be a large financial institution and the adequacy of the foreign investor should be tested in a strict review. Further to these principles, minimum standards have been announced: investments should be for at least three years and $5 \%$ stakes, the investing institution should bring forward a director to sit on the board; the institution should not have more than two strategic investments in Chinese banks and the foreign investors should bring technical and network support (People's Net - Jiangnan Times, 2005; Yu F., 2005). According to new licensing rules published in early 2006, foreign investors in Chinese financial institutions should have a long-term orientation, have a large asset base (at least USD10bln for investing in a commercial bank, less for rural institutions), have a good international credit rating, have been profitable in the last two consecutive years, show sound internal controls and enjoy a favourable (economic and supervisory) environment at home.

Capital and expertise is what foreign banks are expected to bring, but not control. Control will remain in the hands of the state, for smaller and larger banks. The state regularly reiterates its unwillingness to relinquish full control. Such assertions have been heard from central bankers, bank regulators and other high ranking government officials. Most of the foreign influence is likely to be felt in the area of corporate governance - and to serve the interests of the state.

The best example with foreign investors came with Shenzhen Development Bank. In order to clean the bank's books, foreign investors were accepted to take a strong share of the business (the capital share was less than $20 \%$ but the board director and staffing was partially in the hands of the investor). A few years later, the trick proved to be a success. The bank is clean and was sold at a great profit for the foreign investor as well. The local authorities did not need to pay too much for that and control returned to Chinese hands.

The introduction of foreign investors and the opening of the banking sector to competition will not change much the position of the Chinese state. Pei Minxin (2006) writes that "[p]artial reforms have thus created a hybrid, albeit state-centred, system that allows these elites to perpetuate its privileges". For him, even foreign entry into banks' equity is only a way for the state to strengthen itself. As two China observers mentioned, "China's communist cadres have discovered that equity capital, like state banks' loans in the old days of central planning, does not have to be repaid. And

\footnotetext{
${ }^{17}$ This was done in mid-2000s following a controversial discussion in China about the usefulness of foreign investors.
} 
while investors' funds do come with some strings attached, including international-standard accounts and disclosure requirements, this is a small price to pay considering how little control the state has had to relinquish in the process" (Mitchell T. and Lau J., 2006).

With their limited influence (at most a combined $25 \%$ of the banks' capital) over decisions in Chinese banks, foreign investors might as well settle for taking their dividends home without much reforms (or only those reforms necessary to ensure steady investment gains) - without embarking for a full marketisation of the banking system, which is not in the interest of the state.

Looking back at the re-formulated tiyong moto, the reader can now understand why the specific Chinese regulatory framework still results in strong banks even though it contradicts evidence worldwide.

Chinese officials and regulators act in the interests of the state and not of the public. They are all supposed to work to ensure that the state keeps sufficient capacity in action and power. As a result there is an independent private sector oversight to ensure information transparency - but which serves the interests of the state in the end.

Furthermore, the regulators still exercise control over the provision of information and the transparency of the institutions they are supposed to control with the goal of reducing risks to the state (risk of its power being withdrawn). Market discipline or information transparency is advocated but not to fulfil the interests of private investors or of the public at large, but the internal stakeholders and the state in the end. The dissemination of information is promoted within the state and its structures and "accidentally" to the outside.

This at the same time provides the argument for a strong regulator (in front of the banks but not the executive). To ensure the right flows of information and of financial resources and that these do not reach outside the framework, it is required that banks remain sheltered from too much competition or outside interests. A small dose of competition and outside influences is sufficient to provide a counter-balance to the potentially damaging misallocation or even dilapidation of resources (either through bad lending decisions or through corruption). A negative effect of such arrangement to be reckoned with is that some corruption in lending and in banks will remain. It appears that Chinese regulators are prepared to pay that price to ensure their own model and their own power is undiminished.

The private market and private players have only an instrumented role to play and are intended to delegate their oversight duties to the state. The state remains powerful in that it delegates its own oversight only one step below: to the regulatory agencies and which remain fully dependent of it.

\section{State interest view}

Compared to the opposing views or approaches to bank regulation (Barth, J. R., Caprio, G. Jr., Levine, R. 2006), China follows a "state interest view", being neither public nor private - but rather using a closed circuit of state interests where public and private constituencies are satisfied as a by-product (for the public - the state interests also mean that economic development should be boosted and that consumers should be protected and for the private investors: they may take their gains and dividends home but remain in distinctively disadvantaged position in terms of influence and information channels). The state interest view keeps out fully any interested potential entrant (being a private enterprise and borrower or a private investor) - and might only be accepted if it brings in further financial gains (interest paid by private borrowers in lending) or further improves the allocation of resources (technical assistance of private investors - meant to be strategic ones only and not financial ones).

In all fairness one must also acknowledge that the state recaps the gains but also - where they might arise - the losses due to bank failures. The state also provides the incentives for managers to do good in the interests of the state: the highest penalty is to be taken out of the framework - which is rarely used (only in strong corruption cases or where loyalty is not given anymore). This is not too much an 
issue because the paramount goal of system stability means that too high risk taking is not necessary either.

From lending to state borrowers and a small public base, the banks can reap privileges in terms of continuity of their franchise and of their existence, by being rewarded for supporting the survival of the state. Not doing so would put bank gains at risk of not being earned (lending to SOEs is less risky than to private enterprises from which repayment might not be easily guaranteed). Taking too many risks in banking is thus not advisable - especially in view of the sizeable potential benefits. At the same time, regulation will not impede the development of the banks to generate profits (for example PBOC keeps a deposit and a lending rate - sufficiently one apart from the other so as to ensure a sound margin for banking business).

In conclusion we find that - while in other countries more state has meant largely poorer efficiency in banking and higher instability of the banking system - this does not seem to be the case for China. In China, the state capture of the banks appears to be mostly a blessing rather than a liability - for now at least. Control by the state has changed its tools and channels but has increased its scope.

\section{Conclusion}

All is not well in China either: the current arrangement is not without risks. Increasingly power is being transferred to the generalist faction which uses more leeway in enforcing the rules set by the technocratic faction. This issue is important because regulators require the cooperation of local authorities to achieve their goals.

With the growing power of local authorities and of the generalist faction, the capacity of the central government or technocratic faction has been eroded. More worryingly, the growing transfer of power towards the periphery has also meant that the establishment of a truly private and independent alternative is fully hampered. The private and independent arrangements that have been able to exist up to now (for example foreign shareholders, international rating agencies, external auditors) owe their very existence to the necessity for the technocratic faction to have reliable information about the banking industry it wishes to control.

A transition from socialist banking to a market oriented system has failed to become a revolution because the underlying structures continue to serve the same purposes: that is the interests of the state solely. This was termed a "trapped transition" by Minxin Pei (2006). The banking system is geared towards producing better returns to the state - the system is dealing with itself in a closed circuit. There is no incentive for further banking reforms other than those that ensure the current status quo can endure.

For the time being, the current mechanisms offer what the state requires, but it remains to be seen if in the long term such arrangement is still viable and still fulfils its purpose. As long as the state is not only a predatory one but also offers on balance growth and development (or even a safety net in times of crisis), it is likely that the status quo will not be challenged.

Thus the greatest danger to the status quo and to the system's stability is the state itself but only because it is losing effective control to competing layers of authority (generalist versus specialist function). The central government must manage the diverging interests of local authorities and ensure that these constituencies play a neutral role at least. Up to now the private and independent monitoring arrangements have been established at national level only. There is little control over the activities of local financial sectors. To ensure that things do not get awry at local level either, further foreign and private monitoring mechanisms might be useful at lower administrative level as well: higher transparency by strengthening the role of domestic shareholders and stricter enforcement of rules with harsher anti-corruption activities.

Viewed through the tiyong lenses, the tiyong-supervisory arrangement offers a powerful explanation for a supervisory structure which cannot be fully explained otherwise as these fail to recognise the 
strength of such a hybrid model. By doing so China has chosen a path of modernisation without opting for a full westernisation and thus was able to avert any alienation or loss of control or identity over its own banks and its own agenda. The path to modernity is a lively one which is susceptible of evolution and change - a fertile ground for inventions and possibly re-inventions.

Inventions could continue to fit the Chinese model and strengthen the current arrangement: ensuring the continued existence of monitoring mechanisms with for example the further integration of China within the world - as well in banking and supervisory terms. 


\section{Bibliography}

Anderlini, J. (2007) Concern at China banks' appointments, Financial Times, 22 Jun.

Anderlini, J. (2010b) Chinese banks resigned to default, Financial Times, 27 Jul.

[Bai, B.] 白冰 (2010) 管控万亿灰色信贷 [Bureaucrats control trillions in loans] 《财经》 [Caijing Magazine], 4 Jan.

[Bai, X.] 白晓鸥 (2010) 大银行再融资悬念 [Big banks' refinancing suspense] 《财经》 [Caijing Magazine] 28 Feb.

Barth, J., Caprio, G. and Levine, R. (2000) Banking Systems Around the Globe: Do Regulation and Ownership Affect Performance and Stability? Accessed online under www.auburn.edu/ barthjr/papers/Cheeca.pdf [5 Mar. 2006].

Barth, J. R., Caprio, G. and Levine, R. (2006) Rethinking bank regulation - till angels govern (New York: Cambridge University Press).

Barth, J. R., Zhou, Z., Arner, D. W., Hsu, B. F. C. and Wang, W. (ed.) (2007) Financial restructuring and reform in post-WTO China (The Netherlands: Kluwer Law International).

Basel Committee on Banking Supervision (BCBS) (2009) International framework for liquidity risk measurement, standards and monitoring - consultative document (Basel: Bank for International Settlements).

Bekier, M., Huang, R. and Wilson, G. (2005) How to fix China's banking system, McKinsey Quarterly, Jan.

Brehm, S. and Macht, C. (2005) Is a new broom sweeping clean? The emergence of the China Banking Regulatory Commission. Aussenwirtschaft, 60(2) pp. 169-207.

Cai, H. and Treisman, D. (2006) Did government decentralization cause China's economic miracle?, accessed under http://www.sscnet.ucla.edu/polisci/cpworkshop/papers/Treisman.pdf.

[Caijing Magazine] 《财经》(2009a) 地方政府: 融资的狂欢 [Local authorities: financing craze], 08 Jun.

[Caijing Magazine] 《财经》(2009b)宏观审慎监管“中国策” [Macro-prudential supervision 'China policy'], 28 Sept.

[Caijing Magazine] 《财经》(2010a) 信贷潮再汹涌 [Loan tide re-surges], 18 Jan.

[Caijing Magazine] 《财经》(2010b) 民间利率攀升 [Rising informal rates], 12 Apr.

Caprio, G. (2010) Safe and sound banking - a role for countercyclical regulatory requirements? (Washington: World Bank Policy Research working paper 5198).

China Banking Regulatory Commission (CBRC) (2010) Annual report 2009 (Beijing: CBRC).

Cousin, V. (2011) Banking in China. Basingstoke: Palgrave Macmillan.

Demirgüc-Kunt, A. and Detragiache, E. (2000) Does deposit insurance increase banking system stability? An empirical investigation (Washington: World Bank http://info.worldbank.org/etools/docs/library/155468/finsecissues2003/pdf/demirguc_sta bility.pdf).

Demirgüc-Kunt, A. and Detragiache, E. (2009) Basel Core Principles and bank soundess - Does compliance matter? (Washington: World Bank Policy Research working paper 5129).

Dong, B. and Torgler, B. (2010) The causes of corruption: evidence from China (Fondazione Eni Enrico Mattei working paper 72) available at papers.ssrn.com/sol3/papers.cfm?abstract_id=1628107.

Economist Intelligence Unit (EIU) (2006) China Hand - Finance (2006) (London: EIU). Economist Intelligence Unit (EIU) (2010a) China Hand - Finance (2009) (London: EIU). Economist Intelligence Unit (EIU) (2010b) China Hand - Taxation (2009) (London: EIU). [Fang, H.] 方会磊 (2009) 银行次级债“挤泡沫” [Banks' subordinated debt bubble] 《财经》 [Caijing Magazine], 26 Oct. 
Ferri, G. (2008) Banking in China: are new tigers supplanting the mammoths (Hong Kong Institute for Monetary Research: Working paper 05/2008) Mar 2008.

Financial Times (2010) Foreign banks in China, 18 Jun.

García-Herrero, A. (2008) Does the Chinese banking system benefit from foreign investors? BOFIT discussion papers (Helsinki: Bank of Finland).

Goodhart, C. and Zeng, X. (2005) China's Banking Reform: Problems and Potential Solutions. Financial Markets Group Special Paper sp163.

Grimm, M. (2005) Das Finanzsystem Chinas zwischen Markt und Politik [China's Financial System Between Market and Politics] (Baden-Baden: Nomos Verlagsgesellschaft).

Heilmann, S. (2005a) Policy-making and political supervision in Shanghai's financial industry. Journal of Contemporary China, 14(45) Nov., pp. 643-668.

Heilmann, S. (2005b) Regulatory innovation by Leninist means: communist party supervision in China's finance industry, China Quarterly (Cambridge University Press), 181, pp. 1-21.

Heilmann, S. (2008) Experimentation under hierarchy: policy experimentation in the reorganisation of China's state sector, 1978-2008, CID Working paper 172, Center for International Development at Harvard University.

Heilmann, S. (2009) Maximum tinkering under uncertainty: unorthodox lessons from China. China Analysis 73, May 2009 under www.chinapolitik.de.

[Hu, Z.] 胡祖六 (2005) 银行改革需要国际战略投资吗 [Does the Chinese banks reform require international strategic investors?]. 《经济观察报》[Economic Observer], 12 Dec.

Huang, Y. (2008) Capitalism with Chinese characteristics - entrepreneurship and the state (New York: Cambridge University Press).

Huang, Y., Saich, T. and Steinfeld, E. (eds) (2005) Financial Sector Reform in China (Cambridge: Harvard University).

[Huo, K.] 霍㑆, [Wang, J.] 王晶, [Yu, H.] 于海荣 and [Wang, L.] 王露 (2009) 货币宽松到何时? [When is it right to loosen monetary policy?] 《财经》 [Caijing Magazine], 20 Jul.

IMF \& WB (2005) Financial Sector assessment - a handbook (Washington: IMF \& World Bank)

IMF \& WB (2009) Revised approach to financial regulation and supervision standards assessments in FSAP updates (Washington: IMF \& World Bank)

IMF \& WB (2009) The financial sector assessment program after 10 years - background material (Washington: IMF \& World Bank)

[Jing, X.] 景学成 (2005) 走向现代金融制度一兼论中国金融业『入世』[Towards a Modern Financial System - China's Finance Industry Entering the WTO] (上海 [Shanghai]: 上海财经 大学出版社 [Shanghai Finance and Economics University Press]).

Li, T. and Wen, X. (2009) Bank: Slowdown Tests Credit Control, Caijing Magazine, 4 Feb.

[Li, T.] 李涛, [Wen, X.] 温秀 and [Zhang, M.] 张曼 (2009a) 博弯信贷政策 [Playing the lending policy] 《财经》[Caijing Magazine], 14 Sept.

[Li, T.] 李涛, [Wen, X.] 温秀 and [Zhang, M.] 张曼 (2009b) 信贷接力棒 [Lending relay race] 《财经》[Caijing Magazine], 26 Oct.

[Luo, J.] 罗金生 (2002a) 何种银行产权安排更有利于经济转轨 [Which bank -property rights arrangement is more auspicious to the economic transition?]. 《财贸经济》 [Finance and Trade Economy], 4, pp. 20-24.

[Luo, J.] 罗金生 (2002b) 利益博恋与不良债权的形成 [Interest games and the apparition of non-performing debts]. 《经济理论与经济管理》[Economic Theory and Economic Management], 1, pp. 22-25.

Mandanis Schooner, H., Taylor, M. W. (2009) Regulation of Global Banking: Principles and Policies (Burlington: Academic Press). 
McGregor, R. (2009) The party organiser, Financial Times, 30 Sept.

McGregor, R. (2010) The party - the secret world of China's communist rulers (New York: HarperCollins Publishers).

McKinsey Global Institute (MGI) (2006) Putting China's Capital to Work: The Value of Financial System Reform (Sydney: McKinsey \& Co).

Miller, A. (2008) The CCP Central Committee's Leading Small Groups, China Leadership Monitor, No. 26, accessed under http://www.hoover.org/publications/china-leadershipmonitor/article/5689.

Mitchell, T. and Lau, J. (2006) A Piece of the Action: Why investors are fired up by Chinese IPOs. Financial Times, 1 Jun.

Naughton, B. (2007) Strengthening the Center, and Premier Wen Jiabao (Hoover: China Leadership Monitor, No. 21) accessed under http://media.hoover.org/sites/default/files/documents/CLM21BN.pdf.

Pei, M. (2006) China's trapped transition - the limits of developmental autocracy

(Cambridge: Harvard University Press).

People's Bank of China (PBOC) (2005), 中国金融稳定报告 (2005) [China Financial Stability Report 2005] (Beijing: PBOC).

[People's Net - Jiangnan Times] 人民网-江南时报 (2005) 国家不再为银行经营亏损埋单 [The state will not foot the bill again for banks' operational losses].

Podpiera, R. (2006) Progress in China's Banking Sector Reform: Has Bank Behavior Changed? IMF Working Paper (WP/06/71, Mar.) (Washington, DC: IMF).

PriceWaterhouseCoopers (PwC) (2009a) Chinas' enterprise bankruptcy law: can it help foreign financiers recover their debts? Accessed under http://www.pwc.com/gx/en/banking-capital-markets/journal/journal-0709-chinasenterprise.html.

PriceWaterhouseCoopers (PwC) (2009b) NPL Asia Newsletter (s.I.: PwC).

PriceWaterhouseCoopers (PwC) (2009c) Chinese bankers survey 2009 - executive summary, accessed in Oct 2009 under http://www.pwchk.com/webmedia/doc/ 633922589297244455_bcm_cn_bankers_survey_sep2009.pdf.

[Qiao, X.] 乔晓会, [Dong, Y.] 董欲晓 and [Yuan, M.] 袁满 (2010) 金监“三会”新政 [New finance regulatory policies from the three regulatory commission] 《财经》[Caijing Magazine] 18 Jan.

Ramos, R., Ma, N., Meng, J. and Inamdar, T. (2005) China Banks - The USD 10 bln Question: Where to for Bank Reform? (New York: Goldman Sachs).

Sapienza, P. (2004) The effects of government ownership on bank lending. Journal of Financial Economics, 72, pp. 357-384.

[Shen, M.] 沈明高 (2009) 警惕“信贷财政化” [Warning about the politicization of lending] 《财经》[Caijing Magazine], 8 Jun.

Shih, V. (2004) Factions Matter: Personal networks and the distribution of bank loans in China. Journal of Contemporary China, 13(38) Feb., pp. 3-19.

Shih, V. (2005) China's uphill battle for stronger banks. Far Eastern Economic Review, 168(10) Nov.

Shih, V. (2009) Factions and finance in China - elite conflict and inflation (New York: Cambridge University Press).

Shih, V., Huang, L. and Lee, J. (2005a) Stuck in the quicksand. China Economic Quarterly, Q4, pp. 48-51.

South China Morning Post (2010) Money is no object - as long as ABC gets listed, 10 Jul. Spence, J. D., 1990: The Search for Modern China, New York: Norton \& Co. 
[Sun, M.] 孙铭 (2005) 独立董事与党委是什么关系? [What is the relation between the directors and the Party Committee?]. 发展月刊[Development Monthly], 1(171) pp. 14-15.

[Sun, M.] 孙铭 (2006) 五部委紧急叫停打捆贷款进一步加强宏观调控 [To increase macroeconomic adjustments, five ministries and agencies urge to end the provision of bundle loans]. 21 世纪经济报道 [21st Century Business Herald]. 12 May.

Tan, J., Li, S. and Xia, J. (2007) When iron fist visible hand and invisible hand meet - firmlevel effects of varying institutional environments in china, Journal of Business Research, doi:10.1016/j.jbusres.2007.03.003.

The Economist (2006), Atomised, 1 Jun.

The Economist (2010a) China's financial system Red mist, 4 Feb

The Economist (2010b) Shell game Beijing signals a crackdown on borrowing by local governments, 11 Mar.

The Economist (2010c) Home truths China's economic boom can survive a property bust, 27 May.

The Wall Street Journal (2010a) International Finance: CCB Dials Back Loan Amounts --Under Guidance From China, Lending Quota Is Cut by 20\%, 9 Feb.

The Wall Street Journal (2010b) China Cracks Down on Loan Repackaging, 6 Jul.

[Wang, C.] 王聪 (2005) 加快建立存款保险制度势在必行 [Speeding up the establishment of a deposit insurance scheme is a must]. 《中国金融》[China Finance], 27 Oct.

Wang, Z. (2009) China's banking industry: moving towards in accord with reform and opening, in: Zhu, M., Cai, J. and Avery, M. (ed.) (2009) China's emerging financial markets challenges and global impact (Singapore: John Wiley \& Sons), pp. 73-90.

Wei, W. (2005) The Banking Law System in Transitional China - a Comparative Review in the Light of EU Banking Rules (Zürich: Schulthess Juristische Medien).

Weigelin-Schwiedrzik, S. (2004) Zentrum und Peripherie in China und Ostasien, in WeigelinSchwiedrzik, S., Linhart, S. Ostasien 1600 - 1900 (Wien: Promedia) pp. 88-92.

[Wen, X.] 温秀, [Zhang, M.] 张曼 and 方会否 [Fang, H.] (2009)信贷：7万亿怎样炼成？

[Lending: what about the 7trn?] 财经》 [Caijing Magazine], 20 Jul.

Wen, Y. (2005) 银行业反腐三题 [Three topics on corruption in the banking industry]. 《财经 》[Caijing Magazine], 26 Dec.

World Bank (WB) (2010) Doing Business Report 2009 (Washington: World Bank).

$\mathrm{Wu}, \mathrm{X}$. (2005) Conditions and Environment for Improving Corporate Governance Structure of China's Financial Enterprises. Speech by Ms Wu Xiaoling, Deputy Governor of the PBOC, at the 2005 China International Finance Development Forum, 23 Apr.

[Xiao, Z.] 萧灼基 (ed.) (2005) 中国金融市场分析与预测 - 2005 年金融金皮书 [Analysis and Forecast of the Chinese Financial Markets - 2005 Finance Gold Book] (北京 [Beijing]:经济科 学出版社 [Economic Sciences Publishing House]).

Xie, P. 谢平 (2006)与不良资产有关的十大串谋 [Ten collusions related to non-performing assets]. 《财经》 [Caijing Magazine], 20 Mar.

[Xie, P.] 谢平 and [Lei, L.] 陆否 (2005) 金融腐败求解 [Financial corruption report]. 《财经》 [Caijing Magazine], 24 Jan.

Yan, H. and Huang, Y. (2008) Deposit insurance and banking supervision in China: the agenda ahead. The Geneva Papers, 2008 (33), pp. 547-565.

[Ye, W.] 叶伟强 and [Hu, J.] 胡蛟 (2006) 吴晓灵谈金融改革 [Wu Xiaoling discusses financial reforms]. 《财经》 [Caijing Magazine], 20 Feb.

Zhang, M. (2009) Central Bank Imposes One-year Bills on Some Banks, Caijing Magazine, 15 Sept. 
[Zhang, X.] 张小彩 (2004a) 利率市场化 “行路难” [The difficult way to marketisation of interest rates]. 《财经》[Caijing Magazine], 29 Nov.

[Zhang, X.] 张小彩 (2004b) 专访中央汇金公司总经理谢平 [Interview with Xie Ping, General Manager of Central Huijin Co,]. 《财经》 [Caijing Magazine], 2 Nov.

Zhou, X. (2005) 周小川: 国有商业银行如何充实资本 [Zhou Xiaochuan: How SOCBs should replenish their capital]. 《财经》[Caijing Magazine], 28 Nov.

\section{References for laws and regulations.}

1. 中华人民共和国商业银行法(修正) [Commercial banking law], first issue 1995, revision 2003.

2. 中华人民共和国银行业监督管理法 [Law of banking supervision and administration], 2003.

3. 中华人民共和国中国人民银行法 (修正) [Law of the People's Bank of China], first issue 1995, revision 2003.

4. 个人债权及客户证券交易结算资金收购意见 [Opinion on purchasing personal creditor's rights and client securities transaction liquidation funds], 2004.

5. 商业银行信息披露暂行办法 [Provisional rule for the information disclosure at commercial banks], 2002.

6. 商业银行资本充足率管理办法 [Regulation governing the capital adequacy of commercial banks], 2004.

7. 股份制商业银行风险评级体系 (暂行) [Risk grading system for JSCBs (provisional)], 2004, amended through 商业银行风险监管核心指标（试行）的通知 [Notice on commercial banks' risk supervision core indicators (provisional)] in 2005.

8. 外资银行并表监管管理办法 [Rule governing the consolidated supervision of foreign banks], 2004.

9. 金融机构摊消条例 [Rule on dissolution of banks], 2001.

10. 商业银行次级债券发行管理办法 [Rules on the issuance of subordinated bonds by commercial banks], 2004.

11. 中华人民共和国企业破产法 [PRC Enterprise bankruptcy law] 2006.

12. 中华人民共和国公司法 [PRCcompany Law] 2005.

13. 关于完善商业银行资本补充机制的通知 [Notice on mechanisms to perfect commercial banks' capital buffer], 2009.

14. 关于加强地方政府融资平台公司管理有关问题的通知 [Notice on issues relevant to the strengthening of the management of local government financing platforms], 2010.

15. 中华人民共和国外资银行管理条例 [PRC Management ordinance on foreign banks], 2006 as well as 中华人民共和国外资银行管理条例实施细则 [Implementation guidelines on PRC Management ordinance on foreign banks], 2006.

16. 关于进一步改进外商投资审批工作的通知 [Notice on improving approval of foreign investors], 2009 and 境外投资管理办法 [Management rule on foreign investors], 2009.

The above lists only those regulations which were cited in the text, it is not an exhaustive list of banking relevant laws and regulations. 